\title{
Computer-Aided Design, Modeling and Simulation of a New Solar Still Design
}

\author{
Jeremy (Zheng) Li \\ School of Engineering, University of Bridgeport, Bridgeport, CT 06604, USA \\ Correspondence should be addressed to Jeremy (Zheng) Li, zhengli@bridgeport.edu \\ Received 3 March 2011; Revised 13 May 2011; Accepted 19 May 2011 \\ Academic Editor: Andrzej Dzielinski
}

Copyright ( $) 2011$ Jeremy (Zheng) Li. This is an open access article distributed under the Creative Commons Attribution License, which permits unrestricted use, distribution, and reproduction in any medium, provided the original work is properly cited.

\begin{abstract}
The clean and pure drinking water is important in today's life but current water sources are usually brackish with bacteria that cannot be used for drinking. About $78 \%$ of water available in the sea is salty, $21 \%$ of water is brackish, and only $1 \%$ of water is fresh. Distillation is one of the feasible processes applied to water purification, and it requires the energy inputs, such as solar radiation. Water is evaporated in this distillation process and water vapor can be separated and condensed to pure water. Now, with the change from conventional fuels to renewable and environment friendly fuels sources, the modern technology allows to use the abundant energy from the sun. It is better to use solar energy to process the water desalination since it is more economical than the use of conventional energies. The main focus of this paper is applying computer-aided modeling and simulation to design a less complex solar water distillation system. The prototype of this solar still system is also built to verify its feasibility, functionality, and reliability. The computational simulation and prototype testing show the reliability and proper functionality of this solar water distillation system.
\end{abstract}

\section{Introduction}

The heat from the sun can be applied to water distillation process. Water distillation is the process in which water gets evaporated and vapor passes through the cooling coil [1]. After it gets condensed we can get pure water, leaving the contaminants as a residue in the tank. This process is very useful for removing the inorganic and organic contaminants in the water [2]. There are many approaches applied to water purification and desalination, and solar water distillation is an effective methodology in the application [3]. The solar stills were used in the sixteenth century, and mass production of solar stills was introduced for the first time in the Second World War when the large-scale solar stills were used to support the US military [4]. One solar collection system with radiation concentrated on heat absorber is shown in Figure 1. This system uses Fresnel lenses to improve the system efficiency and overall production of water distiller by focusing the incoming radiation onto the water. The vans are placed at the base of the unit that applies the capillary action of water to enlarge the exposed surface area of the water to absorb more incoming solar radiation for high system efficiency [5].
One application is to use the electrical power generation to increase the fresh water output. Water can be changed to water vapor by heat exchangers and a complex water plumbing system. This solar water distillation system is shown in Figure 2 [6]. Although this system increases the overall water output, the system of heat exchangers, water plumbing, and electrical power generation is too complex to manufacture.

Another application is to build a multiple effect system in which the evaporated water from the first surface condenses at the second surface at the bottom and transfers thermal energy to the second surface. An inclined wicking system is used in an enclosed area to supply the continuous water feeding through the still. The multiple wicks absorbing solar radiation are indicated in Figure 3 [7]. Although the system is simple, the water distillation efficiency is lower.

There are four major methodologies for purifying water including distillation, filtration, chemical and irradiative treatment. Because of unavailability and costs of materials, it is difficult to use few of the above methods. Chemical treatment cannot be used alone as a water purifying procedure and the same thing is with irradiative treatment [8]. Both 


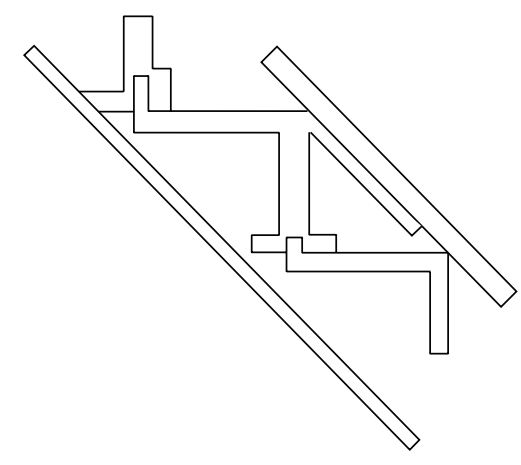

Figure 1: Solar system with Fresnel lenses.

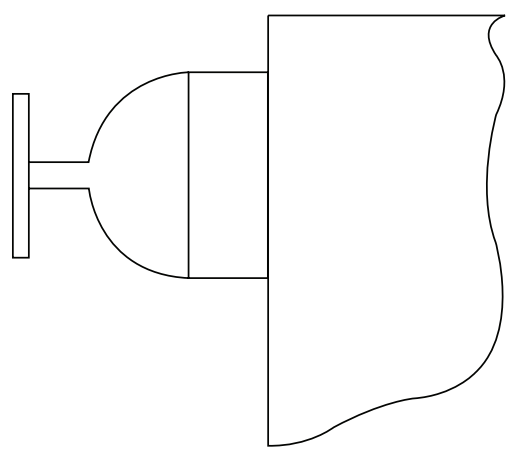

Figure 2: Solar water distillation system by electrical power generation.

treatments are only used to remove certain types of impurities but need involvement of some other technologies [9]. Compared with filtration process, distillation has advantages over filtration as follows [10].

(i) A high quality of water can be achieved.

(ii) Less equipment maintenance is required.

(iii) Any type of water can be purified.

(iv) The process is cheap because it does not need electricity.

(v) The equipment is simple since there are no moving parts in equipment.

(vi) It requires less amount of waste if compared with other techniques.

(vii) Water is cleaner.

Based on the above analysis, the distillation is one major type of processes used for water purification and sunlight can be used as one free energy to generate heat. Sunlight can also be used to accelerate the distillation process. This paper introduces a new solar still design based on computer-aided modeling and simulation and prototype testing.

\section{New Solar Still Design}

It is always beneficial to use solar energy instead of other fuels, such as fossil fuels. Solar stills take out dissolved salts

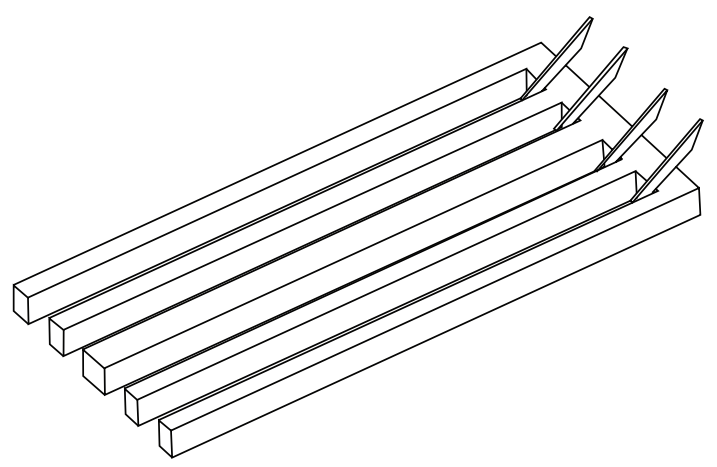

FIGURE 3: Solar water distillation with multiple effect wicking system.

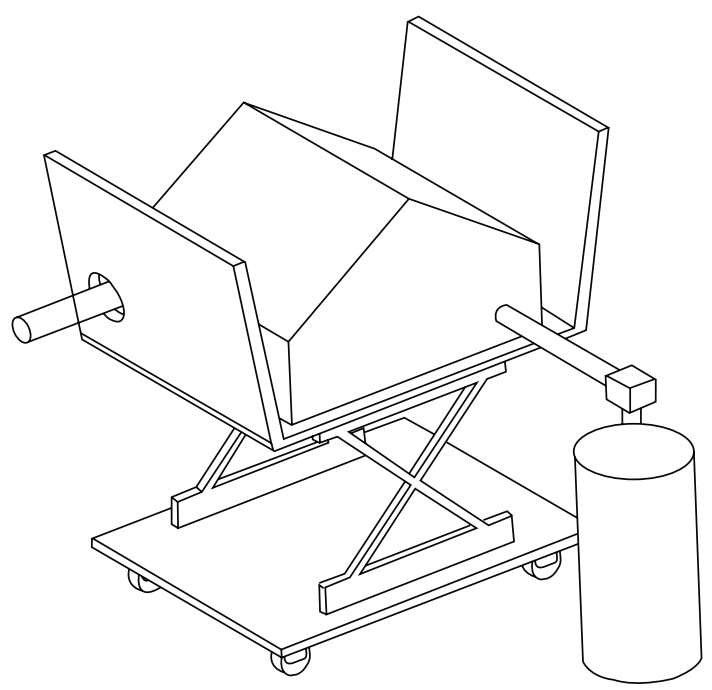

Figure 4: Prototype of the new solar still.

from water. Some factors should be considered in solar still design, such as source of water to be used for purification and solar still efficiency. For better functionality, good material selection, proper part geometry and dimensions are required in the solar still design to get the best efficiency. The solar still should be easy to install and of less maintenance for cost-saving purpose. Higher efficiency can be achieved by considering the main factors: (1) input water temperature at entrance should be high, (2) temperature difference between input water and condensing surface, and (3) less vapor leakage. The input water should absorb a high rate of radiation. System design must keep less heat losses from the floor and walls and maintain water level shallow to utilize the maximum heat. Proper material selections for this solar still include glass of panel with a transmittance of $70 \%$ and concrete base surrounded by the coir and limestone. Coir is used in between the limestone and concrete base to avoid the heat loss to the concrete base. Black limestone is used as the absorber to absorb the heat during day time and also used to keep the base warm after sunset. The prototype of this new solar still is shown in Figure 4.

The main components in this solar still design include transparent glass, absorber, coir, mirror, adjustable base, 
supporter of collector, U-shape channel, reflecting mirror, input water control, and pure water collector. The water distillation cycle in this solar still can be described as follows.

Water is fed from inlet pipe and moves the small ball upwards due to the force of water in the input pipe which opens the inside path for water. Water is then collected in the basin. As the desire level is reached inside the basin, the big ball moves upwards and the small ball moves downwards to block the input pipe so that water could not enter the basin. The whole apparatus gets hot during day time. The sun rays and the rays reflected from the mirror warm the absorber. The absorber sucks the rays and gives the heat to the water which is not pure. Then water starts evaporating and vapor gets generated. The vapor is condensed when it reaches near the top part of the basin. At the top part of the basin the vapor is stuck at the inside wall and converted into the water droplet because the temperature at the upper part is lower than bottom part. These water droplets slide towards the U-type channel and transfer from the U-type channels at both sides. Now both channels transfer water (which is totally impurity free) to the third U-type channel, which is used to transmit the water to the output pipe. Water from the output pipe can be collected to the bucket. We can get pure water from sea or any type of impure water through this distillation technology.

\section{Solar Energy Analysis for Solar Still Design}

The sun consists of hot gases in the form of sphere shape with a large diameter of $1.39 \times 10^{6} \mathrm{~km}$, and the diameter of the earth is $1.27 \times 10^{4} \mathrm{~km}$. Since the sun is too far away from the earth, the light beam by radiation is almost parallel at the earth surface. The energy flux received from the sun at the outside surface of the earth is almost constant with the value of $1367 \mathrm{w} / \mathrm{m}^{2}$. The earth rotates around the sun with certain eccentricity because of its elliptical shape of movement. So during the year the distance between the sun and the earth varies.

If $\theta$ is the angle between the normal to a surface and the beam of flux Ibn, energy flux absorbed on the panel surface is defined by Ibn $\times \cos \theta . \theta$ is also related to latitude $(\varphi)$, declination $(\delta)$, hour angle, and zenith angle. Latitude is considered as an angle which is described as the radial line joining the centre of the earth with, projection on the line in the equator plan. It has values from -90 degree to +90 degree. Declination angle is denoted by $\delta$, and its value varies from +23.45 to -23.45 :

$$
\delta=23.5 \sin \left\{\frac{360}{365} \times(284+n)\right\}
$$

(see [11]) and $\gamma$, with the value between -180 degree to +180 degree, is the surface azimuth angle. $\gamma$ is in horizontal plane that is between the south line and the projection of the normal to the surface in the horizontal plane. Hour angle is denoted by $\omega$ with value from -180 degree to +180 degree. One hour is approximately 15 degree. The decantation can be determined as follows:

$$
\delta=23.5 \times \sin \left\{\frac{360}{365} \times(284+n)\right\} .
$$

Here, $n=327, \delta=-20.68$ degree, Latitude for CT $\varnothing=$ 41.35 degree, Assumed slope of collector $\beta=30$ degree, Hour angle $\omega=15$ degree, Solar radiation $\mathrm{Id}=799 \mathrm{KJ} /$ $\mathrm{m}^{2} \cdot \mathrm{hr}, \mathrm{Ig}=3301 \mathrm{KJ} / \mathrm{m}^{2} \cdot \mathrm{hr}$, Here, Ig is global radiation by hour.

The following mathematical equations can be derived from [11]:

(1) beam radiation $\gamma \mathrm{b}$

$$
\begin{aligned}
\gamma \mathrm{b} & =\frac{\text { tilted surface }}{\text { horizontal surface }} \\
& =\frac{\cos \theta}{\cos \theta z} \\
& =\frac{\{\sin \delta \times \sin (\phi-\beta)+\cos \delta \times \cos \omega \times \cos (\phi-\beta)\}}{\{\sin \phi \times \sin \alpha+\cos \phi \cos \alpha \cos \omega\}} \\
& =1.03,
\end{aligned}
$$

(2) diffusion radiation: tilt factor denoted by $\gamma \mathrm{d}$ and it is the ratio of diffuse radiation flux falling on the tilted surface to the horizontal surface

$$
\gamma \mathrm{d}=\frac{1+\cos \beta}{2}=0.93,
$$

(3) reflected radiation: tilt factor of reflected radiation is denoted by $\gamma$ r.

$$
\gamma \mathrm{r}=\rho\left(\frac{1-\cos \beta}{2}\right)=0.1866
$$

(4) flux on the tilted surface: it is a ratio of flux falling on the tilted surface to the horizontal surface which is given by

$$
\begin{gathered}
\frac{\mathrm{It}}{\mathrm{Ig}}=\left(1-\frac{\mathrm{Id}}{\mathrm{Ig}}\right) \times \gamma \mathrm{b}+\left(\gamma \mathrm{d} \times \frac{\mathrm{Id}}{\mathrm{Ig}}\right)+\gamma \mathrm{r}, \\
\frac{\mathrm{It}}{3301}=\left(1-\frac{799}{3301}\right) \times 1.03+\left(0.93 \times \frac{799}{3301}\right)+0.1866, \\
\frac{\mathrm{It}}{3301}=0.75 \times 1.03+(0.93 \times 0.24)+0.1866, \\
\mathrm{It}=1.1308 \times 3301=3732.7 \frac{\mathrm{KJ}}{\mathrm{m}^{2}} \cdot \mathrm{hr},
\end{gathered}
$$

(5) quantity of output water in liter is calculated by the following formula:

$$
Q=\frac{(\mathrm{A} \times \mathrm{E} \times \mathrm{G})}{2.3} .
$$

Here, area of still $\mathrm{A}=1.56 \mathrm{~m}^{2}$, efficiency of still $\mathrm{E}=$ $30 \%$, energy of global radiation $=19.45$

$$
Q=\frac{(1.56 \times .30 \times 19.45)}{2.3}=3.96 \text { liter. }
$$


TABLE 1: Engineering data of float glass.

\begin{tabular}{lc}
\hline Properties & Value \\
\hline Thermal conductivity & 0.744 \\
Specific heat & 670 \\
Density & 2500 \\
Initial temperature & $20-30$ degree \\
Maximum temperature & 100 degree \\
Transitivity & $>85 \%$ \\
Emissivity & .92 \\
\hline
\end{tabular}

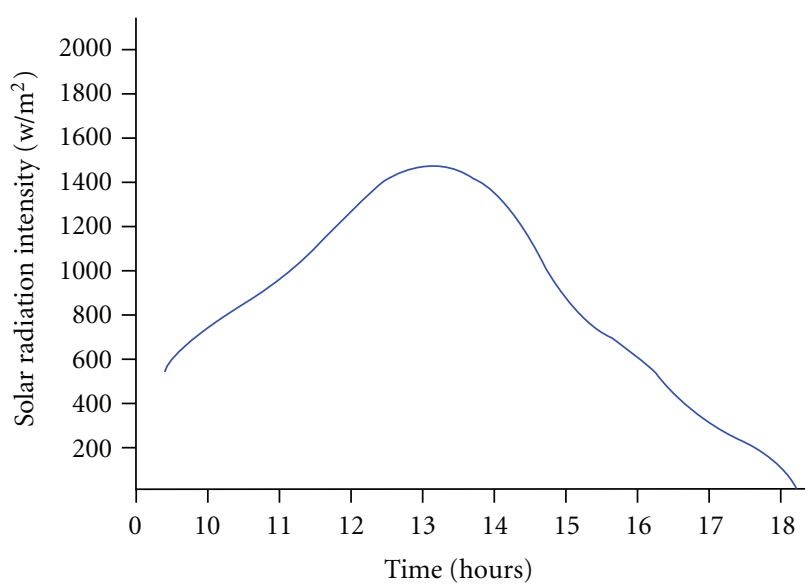

FIGURE 5: Solar radiation intensity of this solar still as function of time.

\section{Computer-Aided Analysis on This Solar Still System}

The computer-aided modeling and simulation is used to design and develop this solar still system.

Table 1 shows the material engineering data of float glass.

Figure 5 shows the computer-aided simulation of solar radiation intensity in this solar still system. It can be seen from the diagram that the maximum solar radiation intensity is $1410 \mathrm{~W} / \mathrm{m}^{2}$.

Figure 6 shows the effect of water output as function of time in this solar still. The distilled water production is proportional to the basin water temperature. If the basin water temperature is increased, the evaporation rate will be increased and more yields will be produced from solar still. When the temperature of water inside the tube is preheated by the incoming solar radiation, the water temperature will be increased. This preheated water needs less heat to evaporate into steam, and distillated water output is enhanced by this solar still. The distilled water output can be found through computer-aided simulation, shown in Figure 6.

Figure 7 shows the distilled water output of solar still as function of basin water depth. The distilled water output will be decreased when water depth in solar still is increased. So the water depth inside the solar basin should be kept lower in order to increase the productivity of distilled water in solar still. From Figure 7, the water depth of

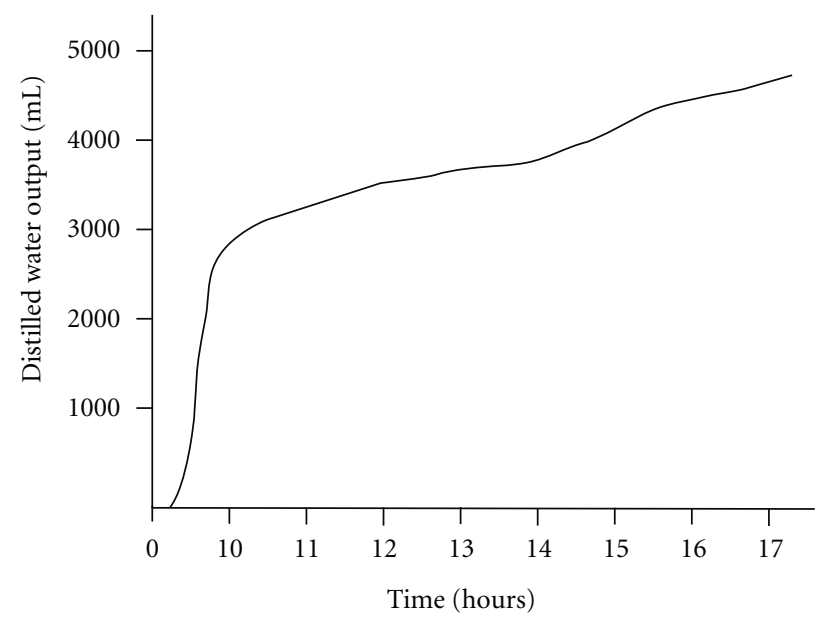

Figure 6: Distilled water output of this solar still as function of time.

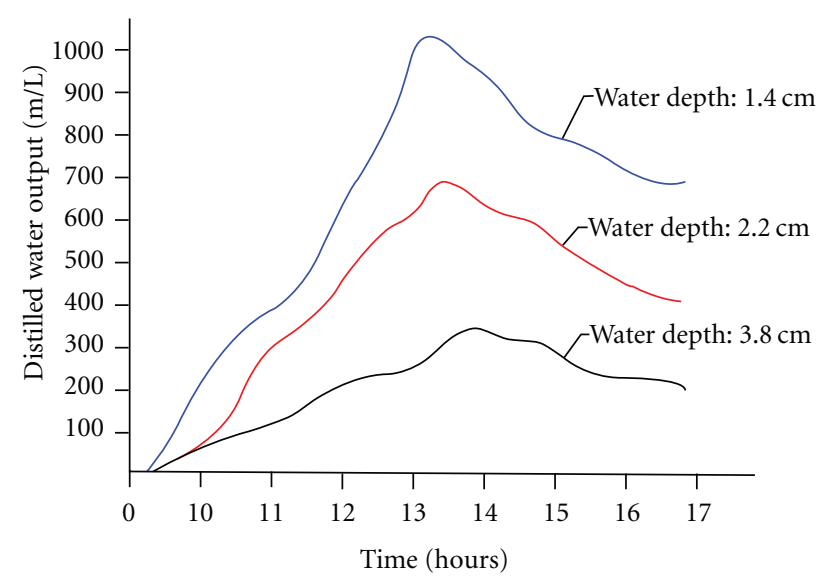

Figure 7: Effect of water depths $(1.4 \mathrm{~cm}, 2.2 \mathrm{~cm}$, and $3.8 \mathrm{~cm})$ on solar still productivity.

$1.4 \mathrm{~cm}$ shows better performance of this solar still than the depth of $2.2 \mathrm{~cm}$ and $3.8 \mathrm{~cm}$. The heat capacity of basin is reduced with the decrease of the water depth which leads to higher temperature inside the solar still. Thus the higher evaporation and condensation improve the distillate water output.

\section{Prototype Tasting on This Solar Still System}

The different water depths were used in the basin, and the amount of water output for each water level was measured daily over a time period of several months. The results indicate that the daily distilled water output is increased if there is a change to a shallower water depth. The several different water depths between $1.4 \mathrm{~cm}$ and $10 \mathrm{~cm}$ were set up and tested. The distilled water output for the depth of $1.4 \mathrm{~cm}$ was about $14.5 \%$ more than the water depth of $10 \mathrm{~cm}$.

The measurements of solar radiation intensity in this solar still prototype show the maximum value of $1425 \mathrm{~W} / \mathrm{m}^{2}$ that is close to the value of $1410 \mathrm{~W} / \mathrm{m}^{2}$ from computer-aided simulation. 
One of the objectives of this paper is to design a solar still that is easy to be manufactured and highly affordable. To design this solar still, the solar basin is made from thermal plastic that can significantly reduce the manufacturing cost. To improve the manufacturability and affordability of this solar still system, most of the components in this solar still system can be molded and produced on a larger scale.

\section{Future Improvement}

(1) Replacing mirrors by sun tracing system can increase the solar concentration.

(2) It is possible to use different types of materials instead of simple glass to increase the heat flow rate.

(3) Providing extra cooling system at the top part can easily change the temperature difference between the top and bottom sections to improve thermal efficiency.

(4) Using multilayer basin instead of single basin can achieve more water output in the same space.

\section{Conclusion}

Both computer-aided modeling/simulation and prototype testing show the reliable function of this solar still system design. Good design parameters determined through computer-aided simulation and prototype testing can help to get acceptable efficiency by increasing evaporation rate at the bottom section and good condensation at the top section. The output water is pure without impurity, and this distillated water can be used for drinking, cooking, and industrial purpose. This water distillation instrument works on solar energy to save the fuels and help to prevent the pollution. Also the plastic molding components in this solar still system can help to lower the manufacturing cost.

\section{References}

[1] S. Lattemann and T. Höpner, "Environmental impact and impact assessment of seawater desalination," Desalination, vol. 220 , no. $1-3$, pp. $1-15,2008$.

[2] F. Trieb and H. Müller-Steinhagen, "Concentrating solar power for seawater desalination in the Middle East and North Africa," Desalination, vol. 220, no. 1-3, pp. 165-183, 2008.

[3] T. Yang, Z. F. Ma, and Q. Y. Yang, "Formation and performance of Kaolin $/ \mathrm{MnO}_{2}$ bi-layer composite dynamic membrane for oily wastewater treatment: effect of solution conditions," Desalination, vol. 270, no. 1-3, pp. 50-56, 2011.

[4] C. Shen, Y. L. He, Y. W. Liu, and W. Q. Tao, "Modelling and simulation of solar radiation data processing with Simulink," Simulation Modelling Practice and Theory, vol. 16, no. 7, pp. 721-735, 2008.

[5] F. Husson Jr., "Solar Collection System with Radiation Concentrated On Heat Absorber Vanes," Patent 4660544, 1987.

[6] D. Deutsch, "Solar Water Distillation System," Patent 5053110, 1991.

[7] L. Weinstein, "High Output Solar Distillation System,” Patent 6355144, 2002.
[8] O. O. Badran and M. M. Abu-Khader, "Evaluating thermal performance of a single slope solar still," Heat and Mass Transfer, vol. 43, no. 10, pp. 985-995, 2007.

[9] I. Al-Hayeka and O. O. Badran, "The effect of using different designs of solar stills on water distillation," Desalination, vol. 169, no. 2, pp. 121-127, 2004.

[10] A. K. Tiwari and G. N. Tiwari, "Thermal modeling based on solar fraction and experimental study of the annual and seasonal performance of a single slope passive solar still: the effect of water depths," Desalination, vol. 207, no. 1-3, pp. 184-204, 2007.

[11] R. A. Messenger and J. Ventre, Photovoltaic Systems Engineering, CRC Press, Boca Raton, Fla, USA, 2004. 

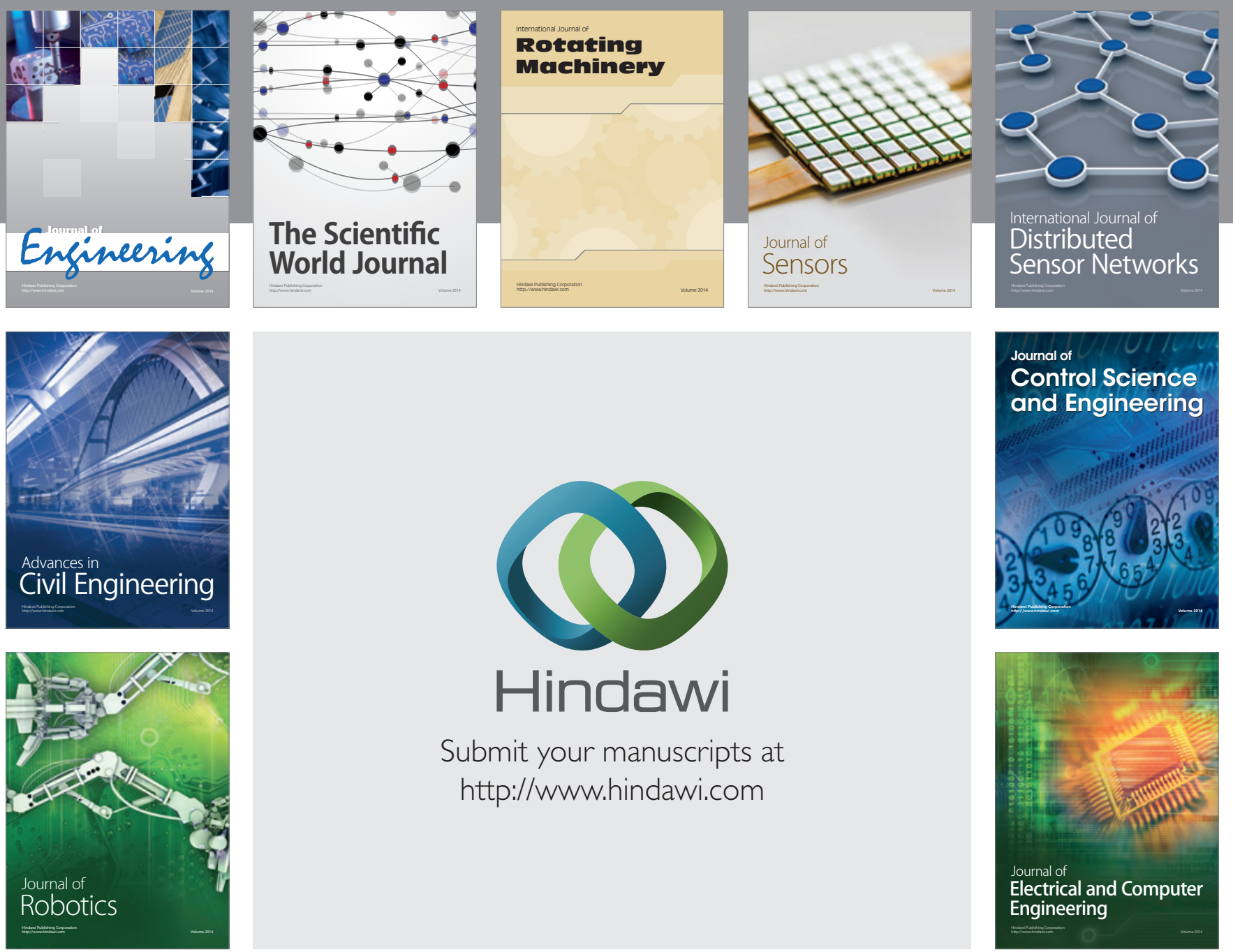

Submit your manuscripts at

http://www.hindawi.com
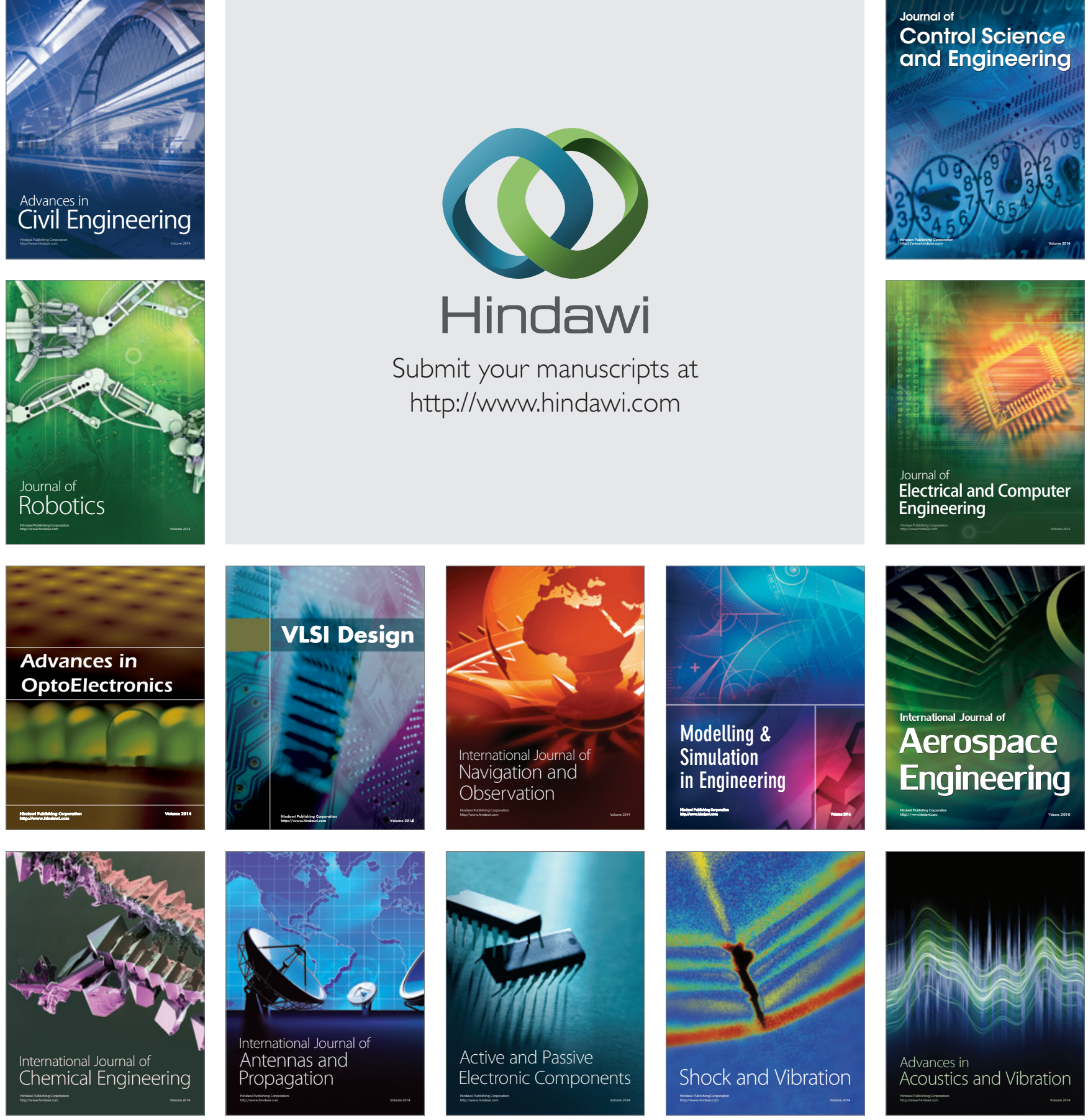